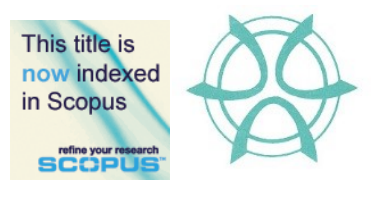

PLANNING MALAYSIA:

Journal of the Malaysian Institute of Planners

VOLUME 19 ISSUE 4 (2021), Page $36-47$

\title{
THE VERTICAL LAND USE ZONING FOR UNDERGROUND SPACE DEVELOPMENT IN MALAYSIA
}

\author{
Farah Zaini $^{1}$, Robiah Suratman ${ }^{2}$, Asmma' Che Kassim $^{3}$ \\ ${ }^{I}$ Faculty of Social Sciences and Humanities \\ UNIVERSITI MALAYSIA SARAWAK \\ ${ }^{2}$ Faculty of Surveying and Built Environment \\ UNIVERSITI TEKNOLOGI MALAYSIA \\ ${ }^{3}$ Department of Built Environment Studies and Technology \\ UNIVERSITI TEKNOLOGI MARA
}

\begin{abstract}
There is a demand for the development of underground space beneath alienated land by a third party other than the surface landowner. Arguments frequently arise because the surface landowner asserts that his rights extend to ownership extension, while the other party wishes to develop the underground space without interfering with the rights of others. Due to Malaysia's absent of land use zoning for underground space, the rights to develop underground space are ambiguous. Using a qualitative approach, this study will examine the role of land use zoning in assisting the development of underground spaces. Thematic analyses revealed three interconnected elements: underground land use zoning, standardisation of land category depths, and a buffer zone for surface and underground space ownership. Additionally, a comparative study was conducted between Malaysia, Hong Kong, China, Japan, and Finland in order to determine the optimal strategy for zoning underground space land uses. At the conclusion of this paper, vertical land use zoning was also proposed.
\end{abstract}

Keyword: underground space, vertical planning, underground land use zoning, comparative study, qualitative study

\footnotetext{
${ }^{1}$ Lecturer at Universiti Malaysia Sarawak Email: zfarah@unimas.my
} 
PLANNING MALAYSIA

Journal of the Malaysia Institute of Planners (2021)

\section{INTRODUCTION}

The terms 'underground space' or 'subsurface' refer to any space beneath the earth's surface, whereas the term 'surface area' refers to the area above the earth's surface (Ronka et. al., 1998). Initially, people used the underground as a part of the caves, where they used it as a shelter from the rain, heat, and threat of wild animals in addition to providing a place to stay. They began to use the basement for living, storage, property disposal, and mining as the evolution progressed. This demonstrates that underground space, particularly in urban areas, can be used for any type of land use and development. Thus, the construction of underground infrastructure appears to be a requirement in tandem with a city's rapid growth (Chow et al., 2002). There is no doubt urbanisation give benefits to the communities (Samat et al., 2019) also lead to economic and social development (Rosni et al., 2016) but it comes with a high demand for infrastructure, residential, and commercial development. However, because surface space is limited, underground space can provide a new and alternative space for development. For example, it will create additional space for the development of infrastructure, utility services, and other purposes unrelated to the above-ground land use.

However, Malaysia's urban plan lacks land use zoning for underground space development. While the majority of underground space development is for public purposes, commercial development is also in demand. The purpose of this article is to examine the land use zoning and development considerations associated with underground space development. The output will detail the elements required for vertical land use zoning, which will aid in the future planning of underground space.

\section{THE FUNCTION OF UNDERGROUND SPACE}

Because urban areas are densely populated, underground space is frequently used to open up a development and alleviate urban issues such as a lack of open space and traffic congestion. Underground space development is critical in making underground spaces one of the solutions to urban problems (Sterling, 1996; Pandey 2019). Not only does added value provide solutions, but it also contributes to sustainable development, and improving environmental conditions also improves the quality of life in cities. Thus, we cannot deny the importance of integrating underground space use into urban planning (Mavrikos \& Kaliampakos, 2007) while also safeguarding underground space resources (Zerhouny et al., 2018).

Urban underground space users can be classified into two types: functional infrastructures and passage and living spaces (Li, 2013). Functional infrastructures are more likely to be pipeline-related, underground storage-related, or utility tunnel-related. Meanwhile, passageways and living areas are concentrated on the subway and underground pedestrian route. Underground space is primarily used for municipal purposes, transportation, and environmental and deepening 
Farah Zaini, Robiah Suratman \& Asmma' Che Kassim

The Vertical Land Use Zoning for Underground Space Development in Malaysia

purposes (Hehua, et.al., 2017). Tunneling is not the only use of underground space, as its potential is much greater. We can see evidence of the limitless use of underground space throughout the world, as summarized in Table 1.

Table 1: Urban Underground Space Development around the World

\begin{tabular}{ll}
\hline Category & Development \\
\hline Facilities and Infrastructure & $\begin{array}{l}\text { Underground Trash Collection, Netherlands } \\
\text { Nagoya Sakae Park Oasis, Japan } \\
\text { Tokyo Underground Drainage Network, Japan } \\
\text { Deep Tunnel Sewerage System, Singapore }\end{array}$ \\
& The Louvre, Paris \\
Building & Underground Science City, Singapore \\
& De France City Development, Paris \\
& Montreal City, Canada \\
Boston City Big Dig, USA & Delhi Metro Project, India \\
Transportation & Kallang Paya Lebar Expressway, Singapore \\
& Mass Rapid Transit, Malaysia \\
Versailles (Innovative road tunnels), Paris
\end{tabular}

However, not all sites, functions, and structures are suitable for underground development, as they must meet certain criteria (Sterling and Godard, 2000). As with surface development, developing underground space requires consideration of several factors, including the type of utilization, the implication of applicable laws and policies, technical aspects, the environment, and also social and economic factors (Goel et al., 2012).

\section{METHODOLOGY}

This article applies the qualitative study. Thus, the discussion in this article is a hybrid of empirical and comparative research. For the empirical study, a pure qualitative approach was used. The respondents were chosen using a nonprobability sampling technique. Purposive sampling was used to select interviewees. Thus, purposive sampling appeared appropriate for this study, as the sampling strategy for selecting respondents for the study area is limited, and only a select group of individuals can respond to interview questions about underground space land use zoning. Five (5) respondents from various agencies with experience in land administration and development participated in the interviews. Table 2 lists the respondents. 
PLANNING MALAYSIA

Journal of the Malaysia Institute of Planners (2021)

Table 2: List of Respondents

\begin{tabular}{ll}
\hline Code & Agency \\
\hline R1 & $\begin{array}{l}\text { Jabatan Ketua Pengarah Tanah \& } \\
\text { Galian (JKPTG) }\end{array}$ \\
R2 & $\begin{array}{l}\text { Jabatan Ukur \& Pemetaan Malaysia } \\
\text { (JUPEM) }\end{array}$ \\
R3 & Land Expert \\
R4 & $\begin{array}{l}\text { Dewan Bandaraya Kuala Lumpur } \\
\text { (DBKL) }\end{array}$ \\
R5 & $\begin{array}{l}\text { Pejabat Tanah dan Galian Kuala } \\
\text { Lumpur (PTGKL) }\end{array}$ \\
\hline
\end{tabular}

The interviews were conducted using semi-structured interview questions. The questions were formatted using a descriptive approach and were based on information about land use zoning and development in Malaysia. The feedback gathered has allowed for a comparison of the collective perceptions of personnel from various government agencies, industries, and land-related experts. The data were analyzed thematically, and the results were used to identify critical components of underground land use zoning, as well as make suggestions and recommendations for improvement.

Meanwhile, Japan, Hong Kong, Finland, and China were chosen for comparative studies due to their excellent examples of vertical land use zoning. While our legislation is distinct, from a geological standpoint, their vertical land use planning is extensive and serves as a model for Malaysia.

According to Lor (2012), comparative studies fall into three categories: single-country studies, few-country comparisons, and many-country comparisons. The amount of abstracted data or information varies according to the number of countries included in the comparative study. Generally, singlecountry studies and comparisons of a few countries employ qualitative approaches, while many-country comparisons employ quantitative methods (Lor, 2012). In comparison to few-country comparisons, data extraction in a singlecountry study is typically more extensive and entails in-depth talks. While the cross-country comparisons concentrate on the correlations between variables that are conceptualised and quantified superficially.

As a result, this study used the strategy of few-country comparisons. Due to the lack of a mechanism for underground land development, the four countries were chosen to be reviewed, compared, and discussed in order to examine the components of vertical land use zoning of underground space development, which are: the need for underground land use zoning, depth standardisation, and the buffer zone in vertical land use. Meanwhile, the tactics 
Farah Zaini, Robiah Suratman \& Asmma' Che Kassim

The Vertical Land Use Zoning for Underground Space Development in Malaysia

used to develop underground space in various nations are being evaluated in order to identify best practises that may be used to improve our system.

\section{THE ANALYSIS: UNDERGROUND LAND USE ZONING}

Three critical factors that will contribute to the development of vertical land use zoning are discussed in this article: the need for underground land use zoning, the standardization of depth, and the buffer zone in vertical land use. This section discussed based on qualitative study: in-depth interview and comparative study. Before we discuss further, Table 3 summarize the comparative analysis for Japan, Hong Kong, Finland and China based on components of vertical land use zoning.

Table 3: The Summary of the Comparative Analysis

\begin{tabular}{|c|c|c|c|c|}
\hline Components & Finland & Japan & Hong Kong & China \\
\hline $\begin{array}{l}\text { The Restrictions } \\
\text { on Development }\end{array}$ & $\begin{array}{l}\text { The } \\
\text { underground } \\
\text { space } \\
\text { development } \\
\text { is restricted } \\
\text { by the } \\
\text { municipal } \\
\text { building } \\
\text { regulations } \\
\text { and the land } \\
\text { use planning. }\end{array}$ & $\begin{array}{l}\text { Since the } \\
\text { landowner } \\
\text { own } 40 \text { meters } \\
\text { below, after } \\
\text { the depth it } \\
\text { can be utilized } \\
\text { for other } \\
\text { development. } \\
\text { However, it is } \\
\text { restricted for } \\
\text { the purpose of } \\
\text { public project } \\
\text { only such as } \\
\text { infrastructure }\end{array}$ & $\begin{array}{l}\text { The practice } \\
\text { only allows } \\
\text { the } \\
\text { underground } \\
\text { space to be } \\
\text { developed } \\
\text { under the un- } \\
\text { alienated } \\
\text { land and for } \\
\text { the purpose } \\
\text { of public } \\
\text { project only }\end{array}$ & $\begin{array}{l}\text { The } \\
\text { underground } \\
\text { space } \\
\text { development is } \\
\text { restricted } \\
\text { based on the } \\
\text { vertical } \\
\text { underground } \\
\text { space zoning }\end{array}$ \\
\hline $\begin{array}{l}\text { The Depth's } \\
\text { standardization }\end{array}$ & $\begin{array}{l}\text { Even though } \\
\text { the depth of } \\
\text { development } \\
\text { is not } \\
\text { standardized, } \\
\text { six meters } \\
\text { underground } \\
\text { is considered } \\
\text { as the depth } \\
\text { that the } \\
\text { surface landowners } \\
\text { can utilize }\end{array}$ & $\begin{array}{l}\text { The Basic } \\
\text { Law of the } \\
\text { Deep } \\
\text { Underground } \\
\text { Space gazette } \\
\text { allow the deep } \\
\text { underground } \\
\text { space } \\
\text { utilization } \\
\text { under the } \\
\text { alienated }\end{array}$ & $\begin{array}{l}\text { The } \\
\text { underground } \\
\text { space } \\
\text { development } \\
\text { can be more } \\
\text { than } 25 \\
\text { meters deep. } \\
\text { The depth of } \\
\text { development } \\
\text { in Hong } \\
\text { Kong on } \\
\text { depends on } \\
\text { the utility, } \\
\text { type and } \\
\text { location }\end{array}$ & $\begin{array}{l}\text { The depths of } \\
\text { development } \\
\text { are divided by } \\
\text { the layer based } \\
\text { on the use and } \\
\text { level. It is } \\
\text { monitored by } \\
\text { the } \\
\text { Construction } \\
\text { Bureau in each } \\
\text { region }\end{array}$ \\
\hline $\begin{array}{l}\text { The } \\
\text { Underground } \\
\text { Space }\end{array}$ & $\begin{array}{l}\text { The } \\
\text { government } \\
\text { has reserved }\end{array}$ & $\begin{array}{l}\text { The Law on } \\
\text { Special } \\
\text { Measures }\end{array}$ & $\begin{array}{l}\text { The HKPSG } \\
\text { have the } \\
\text { special }\end{array}$ & $\begin{array}{l}\text { The land use } \\
\text { guidelines and } \\
\text { procedures are }\end{array}$ \\
\hline
\end{tabular}


PLANNING MALAYSIA

Journal of the Malaysia Institute of Planners (2021)

\begin{tabular}{|c|c|c|c|c|c|}
\hline $\begin{array}{l}\text { Utilization } \\
\text { Land } \\
\text { Zoning }\end{array}$ & $\begin{array}{l}\text { and } \\
\text { Use }\end{array}$ & $\begin{array}{l}\text { the rock } \\
\text { resources in } \\
\text { present for } \\
\text { unclassified } \\
\text { future use of } \\
\text { underground } \\
\text { space } \\
\text { constructions. } \\
\text { The reason is } \\
\text { to identify the } \\
\text { good sites for } \\
\text { the functions } \\
\text { that are } \\
\text { suitable for } \\
\text { locating the } \\
\text { underground } \\
\text { land } \\
\text { development }\end{array}$ & $\begin{array}{l}\text { Related to } \\
\text { Public Use of } \\
\text { Deep } \\
\text { Underground } \\
\text { and the basic } \\
\text { policies } \\
\text { provide the } \\
\text { legal and } \\
\text { administrative } \\
\text { guidelines in } \\
\text { developing } \\
\text { the } \\
\text { underground } \\
\text { space. It is } \\
\text { subjected } \\
\text { within the } \\
\text { power of } \\
\text { Deep } \\
\text { Underground } \\
\text { Use Council }\end{array}$ & $\begin{array}{l}\text { section for } \\
\text { the rock } \\
\text { cavern } \\
\text { development } \\
\text { to emphasize } \\
\text { the role of the } \\
\text { government } \\
\text { agency in } \\
\text { planning and } \\
\text { developing } \\
\text { the } \\
\text { underground } \\
\text { space. The } \\
\text { suitable } \\
\text { zonings for } \\
\text { the surface } \\
\text { and } \\
\text { underground } \\
\text { space } \\
\text { development } \\
\text { is based on } \\
\text { the Outline } \\
\text { Development } \\
\text { Plans }\end{array}$ & $\begin{array}{l}\text { carried out at } \\
\text { the local level. } \\
\text { Independent } \\
\text { zoning plans } \\
\text { drafted based } \\
\text { on the cities' } \\
\text { need. All these } \\
\text { zoning plans } \\
\text { govern the } \\
\text { issuance of } \\
\text { land use rights } \\
\text { and building } \\
\text { permits, as } \\
\text { well as the } \\
\text { regulation of } \\
\text { land } \\
\text { development, } \\
\text { the Law on } \\
\text { Administration } \\
\text { of Urban Real } \\
\text { Estate, } \\
\text { comprehensive } \\
\text { land use plan, } \\
\text { annual land } \\
\text { use plan, } \\
\text { annual real } \\
\text { estate and } \\
\text { development } \\
\text { plan, ar an } \\
\text { urban zoning } \\
\text { plan. }\end{array}$ \\
\hline
\end{tabular}

\section{The Need of Underground Zoning}

Underground space, without a doubt, has the potential to be developed in the future. However, Section 92 B, Part Five (A) of the NLC Act 828 states that the underground space does not reflect the land use above. As a result, a master plan for the development of underground space must be created. The proposal to classify land use according to depth and specific boundaries in order to facilitate future development has elicited a range of responses from respondents.

Vertical underground zoning has been agreed upon by R1, R4, and R5 based on land use category, existing and surrounding development (land economy), and future development. This is because zoning and development of surface land is relatively straightforward, whereas underground space development is quite difficult. At the moment, Kuala Lumpur's zoning does not 
Farah Zaini, Robiah Suratman \& Asmma' Che Kassim

The Vertical Land Use Zoning for Underground Space Development in Malaysia

include a strong draft plan for underground space development. However, respondents suggested that in order to avoid conflicts between surface and underground landowners, it would be preferable if development were restricted to infrastructure and utilities. Additionally, R4 reports that Kuala Lumpur is now investigating trenching utilities. When trenching utilities are shared, underground utility services and providers avoid the need to dig up the land multiple times to gain access to the underground. They simply need to share the access and establish their services. Apart from reserving space for green space, undergrounding utilities contributes to more structured and orderly urban planning.

However, R2 and R3 opposed vertical zoning, believing that future developments could not be predicted. According to them, current trends may become obsolete in the future. They agreed that Malaysia does not need to specify the underground space in terms of layers (zoning) or restrict development; instead, they should leave it alone and adhere to existing rules, regulations, laws, and development frameworks.

Based on the discussions, this study concurs with R1, R4, and R5 regarding the importance of developing a vertical underground space zoning ordinance to serve as a guideline for urban development. This is because rapid urbanization, whether we like it or not, necessitates underground space to support the growth of a city, such as expanding utilities and infrastructure. While the zoning is not as precise as that of surface land, the underground space utilization layers serve as a guide for development. As agreed with the respondents, zoning should be limited to infrastructure projects such as tunneling or utilities such as pipelines.

\section{The Proposed Buffer Zone in Vertical Land Use Zoning}

For underground space zoning in Japan, private land or property rights are limited to 40 meters below ground, at which point the underground land can be used for other purposes. Thus, the government must construct underground facilities on public property or land to avoid paying a hefty sum for privately owned underground property rights under current law. The 'Law' establishes the boundaries of vertical property rights, which serve as the basis for authority decentralisation from the national to the prefectural level. In the case of Hong Kong, the government established a buffer zone between properties, both horizontally and vertically, because support rights are not recognized in Hong Kong under common law. It is critical to establish a buffer zone because development may have an effect on the development rights granted and the associated liability.

According to a review of the countries, the bundle of surface land rights also applies to underground space. To facilitate development, private property ownership has been limited in Japan to 40 meters below ground, while Hong 
PLANNING MALAYSIA

Journal of the Malaysia Institute of Planners (2021)

Kong has established a buffer zone between the layers. According to the respondents, restricting surface landowners' rights to use underground land, as done in Japan, is unsuitable for implementation in Malaysia. The findings indicate that it is preferable if there is no restriction on ownership extension, which means that Section 44 (1) (a) of the NLC Act 828 is valid for application.

On the other hand, this study concurs with the Hong Kong government's strategy of establishing a buffer zone between the surface and underground layers. Figure 1 illustrates the proposed buffer zone in vertical layers. The buffer zone should be determined and included during the underground space alienation process based on the type of development in both spaces. Additionally, the title must clearly state the rights in order to protect and guarantee the landowner's rights as defined in the National Land Code Act 828 and other applicable legal provisions.

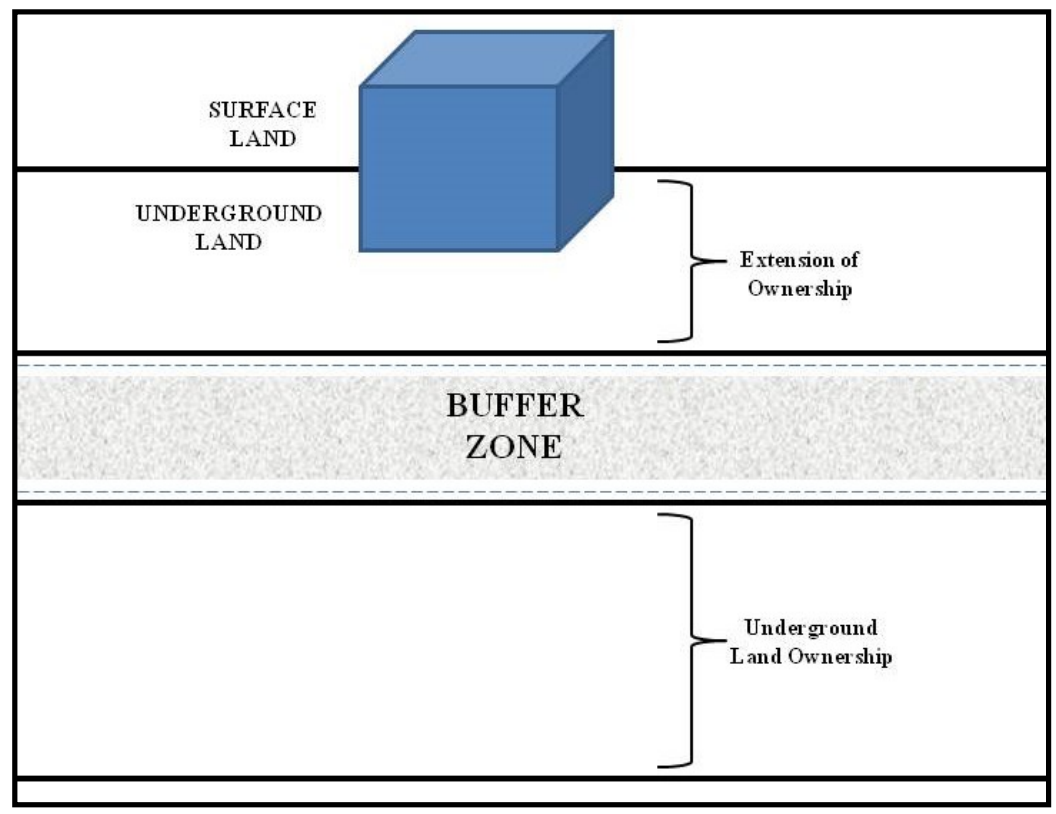

Figure 1: The Proposed Buffer Zone in Vertical Layer

\section{The Standardization of Depth for Land Tenure}

R1 and R3 did not agree on depth standardization. Even though the circular established a minimum depth, the State has yet to publish any rulings on the subject. It is not the case in countries such as Japan, which have standardized the depth of land tenure and are prepared to plan for future underground space utilization and development. It is not necessary to standardize the depth in light of Malaysia's current situation. 
Farah Zaini, Robiah Suratman \& Asmma' Che Kassim

The Vertical Land Use Zoning for Underground Space Development in Malaysia

$\mathrm{R} 2$ agreed that the land, along with the standardized depth, is alienated. R4 had substantiated R2's assertion by demonstrating a straightforward situation. He noted that Malaysia's land development is extremely dynamic. While the land may be zoned for commercial use today, it may be converted to industrial use in another 20 years. Thus, if there is an underground space development beneath, determining the depth and other technical factors is quite complicated. However, if the depth is standardized, the depth remains constant regardless of the zoning. Even if the development above expands, it will not disrupt the existing development. Simultaneously, R5 endorsed R2 and R4's recommendation to standardize the depth. He agreed that if the depth of tenure is standardized, the depth of ownership can be endorsed in the land title upon its implementation.

However, upon further evaluation, this study concluded that there is no pressing need to standardize the depth of land tenure. While it must be acknowledged that underground space is critical for development, in Malaysia, its use is currently limited to infrastructure and tunnelling. While some countries have standardized the depth for the purpose of land alienation for underground development, this is due to issues of land scarcity, extreme weather, and also unforeseeable natural disasters; and the situation is quite different in Malaysia.

\section{THE VERTICAL LAND USE ZONING}

The Helsinki Underground Master Plan is one of the most frequently cited master plans for the development of underground space worldwide. The municipality of Helsinki in Finland developed a master plan for the 10,000,000 m3 underground space, reserving it for long-term development of public and private facilities. The Helsinki Underground Master Plan was implemented to promote and coordinate underground space planning and development, as well as to preserve the rocks designated for sustainable use. This is a statutory plan that details the location and allocation of underground space for utility tunnels and facilities, both existing and planned.

The underground space is one of the solutions for a city's growth because it provides a location for utilities and infrastructures. Due to Malaysia's absent of underground space planning, the findings indicate the importance of vertical underground space zoning as a guideline for urban development. However, the master plan does not have to be as meticulous as the surface land zoning. It simply needs to demonstrate at the very least the layers of underground space use as a point of reference for development. For example, the underground space can be divided into three layers: shallow, medium, and deep. One of the best examples to follow is China, specifically Beijing, where underground space is zoned in a way that is not overly detailed but is sufficient to support underground space use. In China, development is classified into four stages, with depths ranging from 0 to 10 meters, 10 to 30 meters, 30 to 50 meters, and 50 to 
100 meters. The depth of development is determined by human accessibility, which in turn determines how Beijing's underground space is used.

Additionally, the findings stated that the zoning is limited to infrastructure development, such as tunneling, or utility development, such as pipelines. Figure 2 illustrates the proper way to draft the vertical underground space zoning. The Guideline for Infrastructure Utility Planning is a gazette that assists the State Authority, the Local Authority, and the developer in planning for the placement of utility lines in areas where infrastructure is transferred underground. It is only applicable to new construction and redevelopment. As a result, this guideline can serve as a foundation for the authority when it comes time to draft underground space zoning in the future.

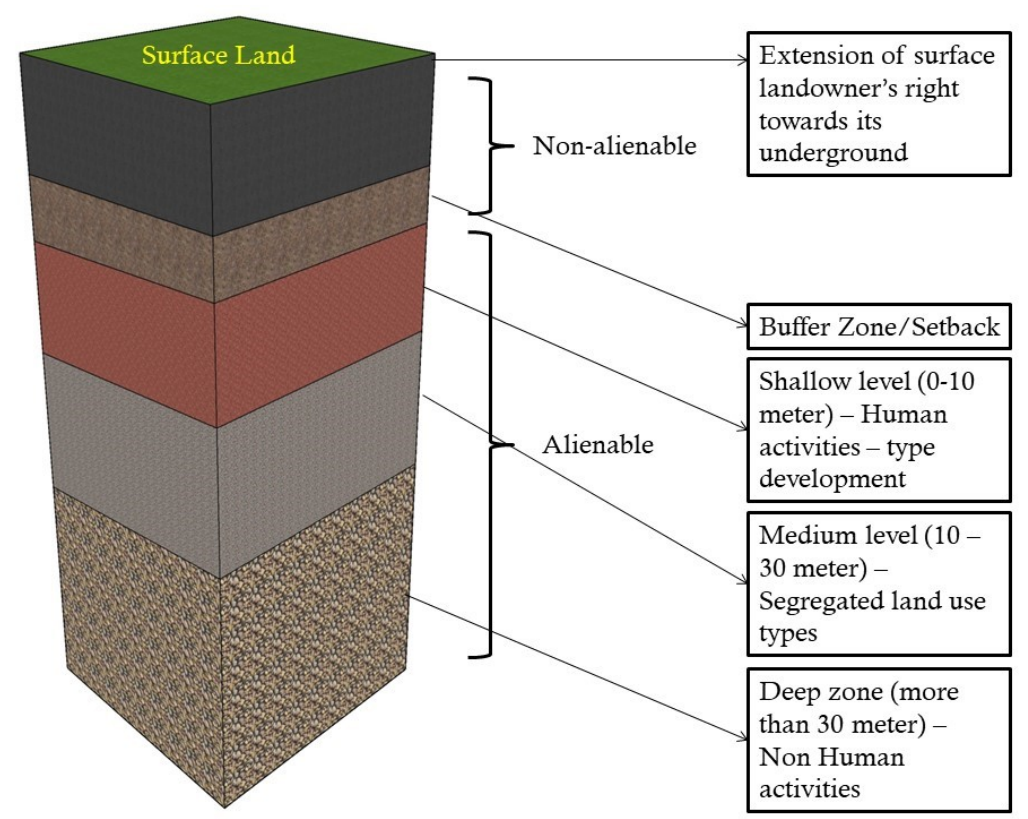

Figure 2: The Proposed of Vertical Land Use Zoning

\section{CONCLUSION}

In summary, the underground space is rich in exploration and development potential and thus has the potential to be used for the greater good of society. While the need for utilizing underground space in Malaysia is still not critical in comparison to other countries, consideration and planning should begin immediately. The study concluded that Malaysia requires vertical land use planning. Through a comparative analysis of Malaysia and the reviewed 
Farah Zaini, Robiah Suratman \& Asmma' Che Kassim

The Vertical Land Use Zoning for Underground Space Development in Malaysia

countries, the optimal strategy for Malaysia's underground space development was determined. While Malaysia's underground space development is currently focused on infrastructure and public benefit, future commercial development is not ruled out.

\section{ACKNOWLEDGEMENTS}

The authors would like to express their gratitude to Universiti Malaysia Sarawak, for support provided of this study and enabled authors to publish the findings of this study.

\section{REFERENCES}

Chow, F. C., Paul, T., Vähäaho, I. T., Sellberg, B., \& Lemos, L. J. L. (2002). Hidden Aspects of Urban Planning: Utilisation of Underground Space. In 2nd International Conference on Soil Structure Interaction in Urban Civil Engineering. Zurich.

Farah Zaini (2016). The Legal Framework for Determining the Land Tenure and Development of Underground Land in Malaysia. Universiti Teknologi Malaysia.

Goel, R. K., Singh, B., \& Zhao, J. (2012). Underground Infrastructures: Planning, Design and Construction. USA: Butterworth-Heinemann.

Hehua, Z., Xiao, L., Fangle, P., Xiaojun, L., \& Chunyan, L. (2017). Development Strategy for Urban Underground Space Planning in China, 19(6), 12-17. https://doi.org/10.15302/J-SSCAE-2017.06.003

Li, H. (2013). An Integrated Strategy for Sustainable Underground Urbanization. École Polytechnique Fédérale De Lausanne.

Lor, P. J. (2012). International and Comparative Librarianship: A Thematic Approach. Global Studies in Library Information.

Mavrikos, A.., \& Kaliampakos, D. C. (2007). Underground Development in Urban Areas: The Birth, The Evolution and The Perspectives of The Trend. WIT Transactiond on Ecology and the Environment, 102, 219-228. https://doi.org/10.2495/SDP070211

Pandey, V. K. (2019). Use of underground space for future needs of Mumbai, India, 8(2), 23-28.

Rönkä, K., Ritola, J., \& Rauhala, K. (1998). Underground Space in Land-Use Planning. Tunnelling and Underground Space Technology, 13(1), 39-49.

Rosni, N. A., Mohd Noor, N., \& Abdullah, A. (2016). Managing Urbanisation and Urban Sprawl in Malaysia by Using Remote Sensing and Gis Applications. Planning Malaysia, 14(4). https://doi.org/10.21837/pm.v14i4.145

Samat, N., Mahamud, M. A., Abdul Rashid, S. M. R., Elhadary, Y., \& Mohd Noor, N. (2019). Urbanisation Beyond Its Core Boundary and Its Impact on The Communities in George Town Conurbation, Malaysia. Planning Malaysia, 17(10). https://doi.org/10.21837/pm.v17i10.627

Sterling, R. L. (1996). Going Under to Stay on Top, Revisited: Results of a Colloquium on Underground Space Utilization. Tunnelling and Underground Space Technology, 11(3), 263-270. 
PLANNING MALAYSIA

Journal of the Malaysia Institute of Planners (2021)

Sterling, R. L., \& Godard, J. P. (2000). Geoengineering Considerations in the Optimum Use of Underground Space. In ISRM International Symposium, Melbourne, Australia.

Zerhouny, M., Fadil, A., \& Hakdoui, M. (2018). Underground Space Utilization in the Urban Land-Use Planning of Casablanca (Morocco). Land. https://doi.org/10.3390/land7040143

Received: $19^{\text {th }}$ August 2021. Accepted: $25^{\text {th }}$ November 2021 